mẹ có con dưới 1 tuổi tại tỉnh Yên Bái năm 2012, Khóa luân tốt nghiệp cử nhân y khoa, Trường Đại học Y Hà Nội.

3. Nguyến Xuấn Hà (2014), Nghiên cứu kiến thức, thái độ, thực hành về chăm sóc trước sinh của phụ nữ có con dưới 1 tuổi tai phường Thủy Biều, thành phố Huế, Luận văn tốt nghiệp bác sỹ y học dự phòng ${ }_{2}$ Trường Đại học Y Dược Huế.

4. Nguyền Thị Thùy Lỉnh (2017), Nghiên cứu tình hình tiêm phòng vacxin uốn ván ở phụ nữ mang thai phường Thủy Biêu, thành phố Huế năm 2016, Luâan văn tốt nghiệp bác sỹ y học dự phòng, Trường Đai học Y Dược Huế.

5. Lê Thị Kim Loan (2012), Khảo sát tình hình chăm sóc trước sinh của bà me có con dưới 1 tuổi tại huyện Châu Thành, tỉnh Long An năm 2011, Luận vắn chuyên khoa cấp I, Trường Đại học Y Dược Huế.

6. Nguyễn Thi Hoài Nhi (2014), Nghiên cứu tình hình cung cẩp và sử dụng dịch vụ chăm sóc trước sinh tại xã Thủy Vân, thị xã Hương Thủy, tỉnh Thừa Thiên Huế năm 2013 , Luận văn tốt nghiêp bác sỹ y học dư phòng, Trường Đaai học Y Dược Huế.

7. Sở Y tế Thửa Thiên Huế (2017), Hành động chăm sóc sức khỏe bà me, tré sơ sinh và trẻ em nhằm giảm tử vong mẹ, tử vong sơ sinh giai đoạn 2017 - 2020, https://syt.thuathienhue.gov.vn/ ?gd $=62 \& \mathrm{cn}=1 \&$ id $=466 \& \mathrm{tc}=6645$, truy cập ngày 3 tháng 11 năm 2018.

8. Trân Nhật Tân (2011), Nghiên cứu kiến thức và thực hành̆ về làm me an toàn của các bà mẹ có con dưới 3 tuổi tại xã Cam Tuyền, huyện Cam Lộ, tỉnh Quảng Trị năm 2010, Luận văn tốt nghiệp chuyên khoa cẩp I, Trường Đai hỏ Y Yước Huế.

9. UBND huyện Phú Vang, tỉnh Thừa Thiên Huế (2017), Hiểu quả của Đế án 52: Góp phần nâng chất lương dân số vùng ven biển, đầm phá huyên Phú Vang, https:// phuvang.thuathienhue.gov.vn/ ?gd $=12 \& \mathrm{cn}=91 \& \mathrm{tc}=1268$, truy cập ngày 4 tháng 11 năm 2018.

\title{
ĐĂC ĐIỂM HÌNH THÁI GAN CHUỘT NHIỄM MÕ̃ SAU UỐNG NƯỚC SẮC LÁ SEN
}

\section{TÓM TẮT. \\ Nghiên cứu mô tả thực nghiệm được tiến hành trên 25 chuột cống trắng với mục tiêu mô tả sự thay đổi cấu trúc hình thái gan chuột nhiễm mõ sau uống nước sắc lá sen. Kết quả nghiên cứu cho thấy: có sự thay đổi lipid trong bào tương tế bào gan chuột khi uống nước sắc lá sen khô. Lượng lipid giảm dần theo số ngày chuột được uống nước sắc lá sen. Cần tiếp tục nghiên cứu định lượng để kết quả đánh giá tốt hơn.}

Tư khóa: hình thái, chuột, gan nhiễm mõ, lá sen

\section{SUMMARY}

MORPHOLOGICAL CHARACTERISTICS OF FATTY RAT LIVER AFTER DRINKING LOTUS LEAF EXTRACT

Descriptive experimental study was performed on 25 white rats. Objective: to describe the structural changes in fatty liver morphology after rats ingested lotus leaf extract. The results showed that: when the rats drank lotus leaf extract, there was a change in lipid in hepatocellular cytoplasm. Lipid decreases with the number of days rats drink lotus leaf extract. Need further quantitative study to better evaluate results.

Keywords: morphology, rat, fatty liver, lotus leaf

\footnotetext{
${ }^{1}$ Trường Đại học Y Dược, Đại học Thái Nguyên Chịu trách nhiệm chính: Bùi Thanh Thủy Email: thuyhptn@gmail.com Ngày nhận bài: 2.3.2021 Ngày phản biện khoa học: 23.4.2021 Ngày duyệt bài: 5.5.2021
}

\section{Bùi Thanh Thủy ${ }^{1}$, Phạm Minh Huệ, Lê Phong Thu ${ }^{1}$, Hoàng Ngọc Hằng ${ }^{1}$}

\section{I. ĐẶT VẤN ĐỀ}

Từ xa xưa, cây sen đã được sử dụng làm thức ăn và là một cây thuốc quen thuộc. Trong lá sen có chứa hàm lượng flavonoid cao, có tác dụng đẩy nhanh quá trình trao đổi chất lipid nên làm giảm lượng cholesterol xâu (LDL - nguyên nhân chính dẫn đến mõ máu, gan nhiễm mõ). Một số bác sĩ cho rằng hoạt chất flavonoid còn làm gia tăng cholesterol tốt ( $\mathrm{HDL})$, qua đó làm bền thành mạch, không những thế flavonoid còn kéo các mô mõ trong cơ quan phủ tang ra chuyển hóa thành dạng tự do để thải trừ ra ngoài. Trong cơ thể, gan là cơ quan đóng vai trò trung tâm trong sư tích trữ và chuyển hóa các chất béo. Gan nhiễm mõ là sự tích lũy của chất béo trong gan vượt quá $5 \%$ trọng lượng của gan.

Trong thực tể hiện nay, đa số người dân có cách dùng chưa đúng, nhiều người uống nước sắc lá sen tươi hoặc lá sen khô để giảm béo một cách tùy tiện, không đảm bảo vệ sinh, hiệu quả không phát huy được tối đa, việc sử dụng liều lượng quá nhiều có ảnh hưởng đến cấu trúc các cơ quan không, việc sử dụng nước sắc lá sen làm giảm mõ trong gan là vấn đề đã được một số tác giả nghiên cứu, nhưng chưa đầy đủ. Theo nghiên cứu của nhóm nhà khoa học đến từ Đại học Tohoku, Nhật Bản trên mô hình thực nghiệm chuột được gầy béo phì bằng chế độ ẳn đặc biệt, sử dụng dịch chiết lá sen có tác dụng 
làm giảm cholesterol rõ rệt do làm giảm sự tiêu hóa, ức chế hấp thu lipid và carbohydrate, tăng tốc độ chuyển hóa lipid và tăng tiêu hao năng lượng. Do vậy, nhóm nghiên cứu tiến hành đề tài với muc tiêu: Mô tả sư thay đổi cấu trúc hinh thái gan chuột nhiếm mỡ sau uống nước sắc lá sen.

\section{II. ĐỐI TƯỢNG VÀ PHƯƠNG PHÁP NGHIÊN CỨU}

2.1. Đối tượng nghiên cứu: 25 chuột cống trắng đực, trọng lượng $100-130 \mathrm{~g}$, được nuôi theo tiêu chuẩn phòng thí nghiệm.

2.2. Phương pháp nghiên cứu: Mô tả thực nghiệm

- Phân lô thí nghiêm: 3 lô

+ Lô chứng (ký hiệu BT): 5 chuột bình thường

+ Lô đối chứng (ký hiệu ĐC): 5 chuột được uống dầu hướng dương Neptune để gây tình trạng gan nhiễm mõ̃. Liều lượng: $1 \mathrm{ml} /$ lần $\times 2$ lần/ngày (tương đương 1,5ml/100g cân nặng) $x$ 7 ngày/mổi chuột.

+ Lô thực nghiệm (ký hiệu TN): 15 chuột được uống dầu hướng dương Neptune với liều lượng: $1 \mathrm{ml} /$ /ần $\times 2$ lần/ngày $x 7$ ngày để gây tình trang gan nhiễm mõ̃. Sau đó các chuột này được uống nước sắc lá sen và chia 3 nhóm:

> Nhóm 1 (TN1): gồm 5 chuột, mỗi chuột được uống nước sắc lá sen, liều lượng $1 \mathrm{ml} /$ /ần $x$ 2 lần/ngày $x 3$ ngày;

> Nhóm 2 (TN2): gồm 5 chuột, mỗi chuột được uống nước sắc lá sen, liều lượng $1 \mathrm{ml} /$ lần $x$ 2 lần/ngày x 5 ngày;

> Nhóm 3 (TN3): gồm 5 chuột, mỗi chuột được uống nước sắc lá sen, liều lượng $1 \mathrm{ml} /$ lần $x$ 2 lần/ngày $x 7$ ngày;

- Nước lá sen được sắc theo công thức: $10 \mathrm{~g}$ lá sen khô x 1 lít nước.

- Quan sát chuột hàng ngày. Lấy mẫu gan chuột ở các lô bình thường, lô đối chứng và lô thực nghiệm sau mỗi thời điểm: 3 ngày, 5 ngày và 7 ngày. Quan sát đại thể gan chuột và lấy mẫu gan chuột làm tiêu bản vi thể.

- Vị trí lấy mẫu: vùng gan phải, kích thước mẫu gan $0,5 \times 0,5 \mathrm{~cm}$.

- Cố định mẫu gan bằng dung dịch Bouin.

- Kỹ thuâat làm tiêu bản: đúc block, cắt mẫu

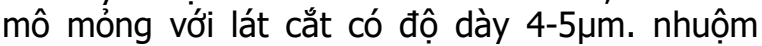
tiêu bản bằng Hematoxylin - Eosin (H.E) thông thường. Tuân thủ các bước kỹ thuật. Tiêu bản được quan sát tiêu bản dưới kính hiển vi quang học Olympus có camera chụp ảnh.

- Chỉ tiêu nghiên cứu: Đặc điểm toàn thân, đặc điểm đại thể, vi thể gan chuột các lô khi nhuộm H.E.

- Địa điểm thực hiện: Bộ môn Mô - Phôi thai học, Trường Đại học Y Dược, Đại học Thái Nguyên.

\section{KẾT QUẢ NGHIÊN CỨU}

3.1. Đắc điểm toàn thân: Chuột ở lô bình thường, lổ đối chứng và lô thực nghiệm đều nhanh nhẹn, tăng cân, lông mượt, không có biểu hiện bất thường.

3.2. Đặc điểm đại thể gan chuột các lô: Khi quan sát đại thể bề mặt gan của các chuột ở các lô bình thường, đối chứng và lô thực nghiệm đều thây hình ảnh bề mặt nhu mô gan chuột mịn, màu hồng sẫm, mật độ mềm, không có xuất huyết.
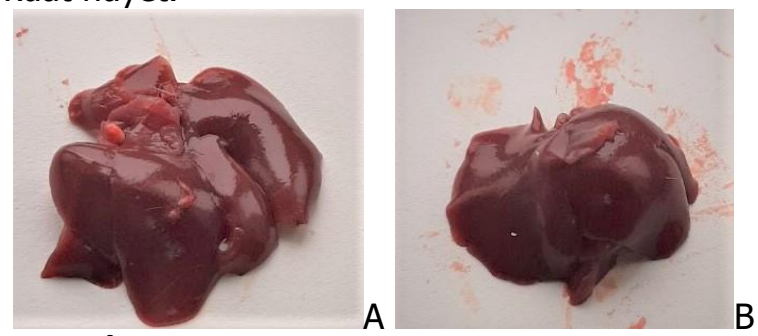

Ảnh 1. Hình ảnh đại thể gan chuột
A. Lô đôî chứng và B. Lô thức nghiệm 3.3 Đặc điểm cấu trúc vi thể gan chuột

Lô chuột bình thường và đối chứng: ở độ phóng đại 40 lần và 100 lần, các tiểu thùy gan chuột có ranh giới không rõ ràng, vùng ngoại vi của các tiểu thùy gan sáng màu, vùng trung tâm tiểu thùy sẫm màu hơn. Các mạch máu trong gan không giãn, lòng mạch máu còn có các tế bào máu.

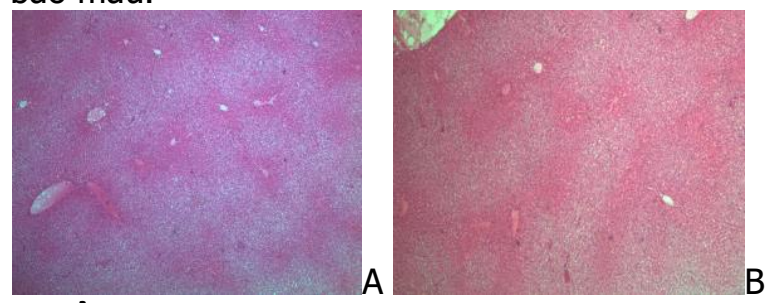

Ảnh 2. Hình ảnh gan chuột: A. Lô bình thường và B. Lô đôi chứng (H.E X4)

Khi chuột uống dầu (lô đối chứng), vùng tế bào gan ở ngoại vi sáng màu. Ở độ phóng đại 200 lần và 400 lần, các tế bào gan ranh giới rõ், nhân tròn, đa số tế bào có 1 nhân, một số tế bào có 2 nhân. Các tế bào gan ở vùng ngoại vi của tiểu thùy gan, bào tương tế bào sáng màu, nhiều hốc sáng to nhỏ chứa lipid hơn so với các tế bào gan nằm gân tĩnh mạch trung tâm tiểu thùy.

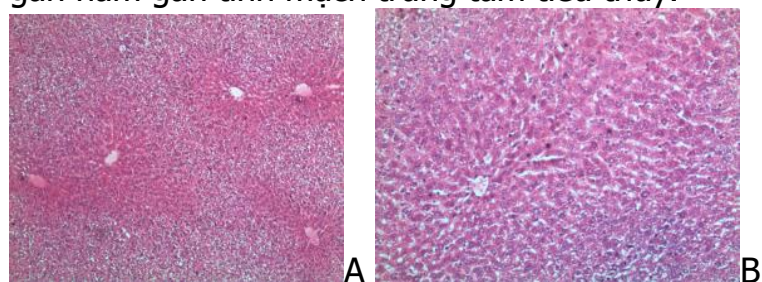



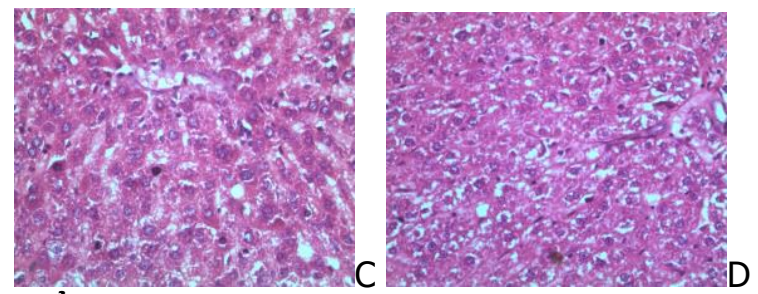

Ảnh 3. Hình ảnh gan chuột lô đôi chứng nhuộm H.E: A X10; B X20; C,D X40

\subsection{Lô chuột thực nghiệm}

3.4.1 ở lồ chuột TN1. Quan sát gan chuột dưới kính hiển vi quang học ở độ phóng đại 40 lần cho thấy: số lượng các tế bào gan ở ngoại vi tiểu thùy sáng màu hơn so với các tế bào gan ở quanh tĩnh mạch trung tâm tiểu thùy. Ở độ phóng đại 100 lần, 200 lần các tế bào gan kích thước to hơn, tế bào gan có bào tương sáng màu chứa nhiều lipid, ở độ phóng đại 400 lần, bào tương các tế bào gan chứa đầy các hạt lipid, màng tế bào mỏng bao quanh.
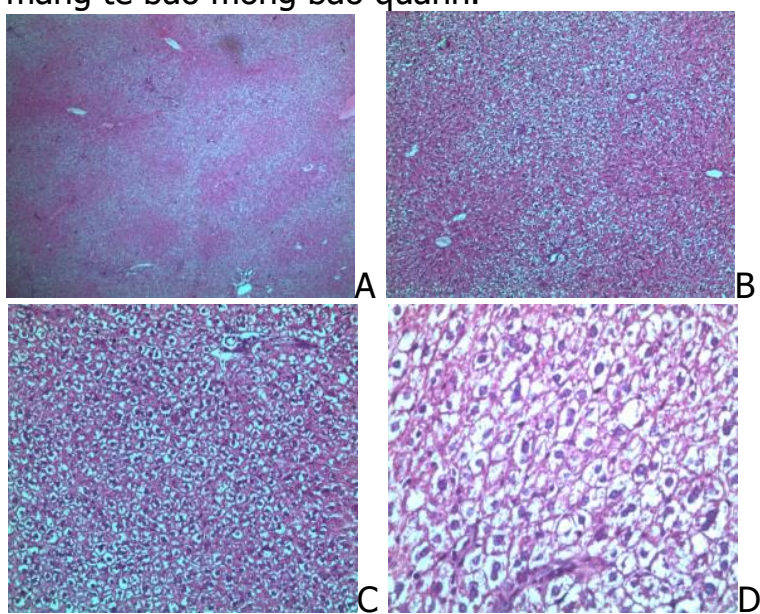

Ảnh 4. Hình ảnh gan của chuột được uống nước lá sen 3 ngày

nhuôm H.E; Ax4; B X10; C X20; D X40

3.4.2 ở lô chuốt TN2. Hình ảnh gan chuột dưới kính hiển vi quang học ở độ phóng đại 40 lần cho thấy: số lượng các tế bào gan sáng màu ở ngoại vi tiểu thùy ít hơn. Ở độ phóng đại 100 lần, 200 lần và 400 lần, các mao mạch nan hoa lòng giãn rộng. Các tế bào gan kích thước đồng đều, tế bào gan có các hạt lipid lớn nằm gần các mao mach.

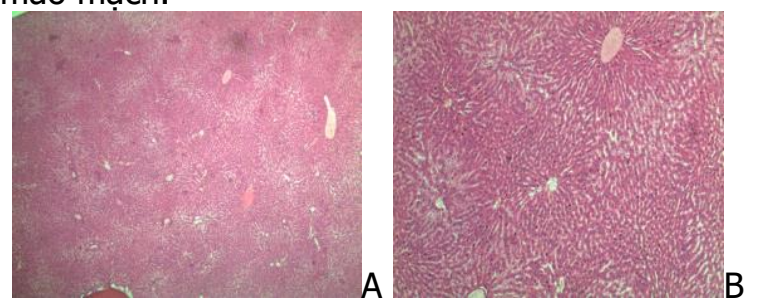

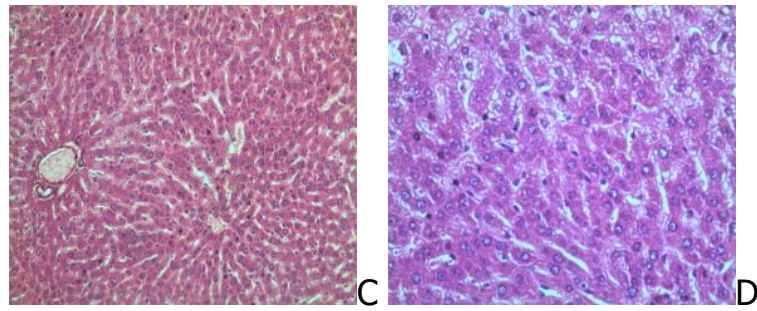

Ảnh 5. Hình ảnh gan của chuột được uống nước lá sen 5 ngày

nhuôm H.E: Ax4; B X10; C X20; D X40

3.4.3 ở lô chuột TN3. Hình ảnh gan chuôt ở lô uống nước lá sen sau 7 ngày dưới kính hiển vi quang học ở độ phóng đại 40 lần, 100 lần, 200 lần và 400 lần, các tế bào gan kích thước đồng đều, bào tương tế bào gan còn có các hạt lipid, số lượng giảm. Nhu mô gan hồi phục về bình thường. Vùng ngoại vi tiểu thùy, còn có các tế bào nhiều lipid trong bào tương.
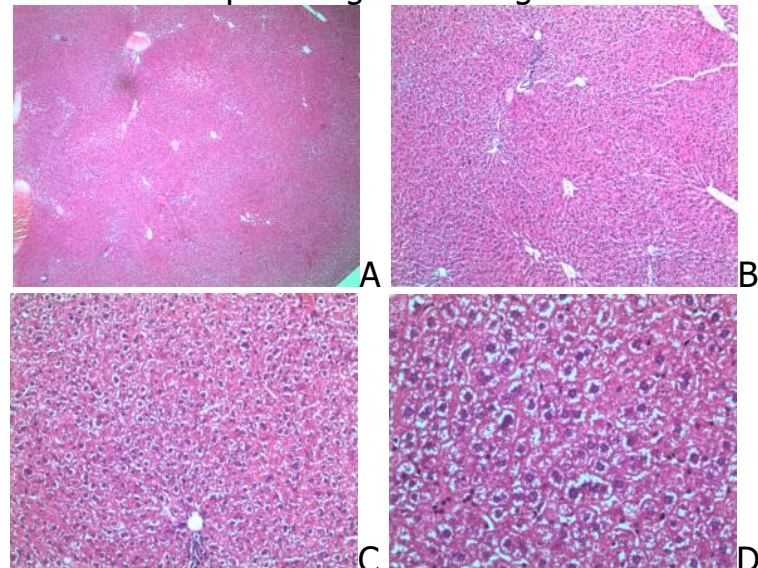

Ảnh 6. Hình ảnh gan của chuôt được uống nước lá sen 7 ngày

nhuộm H.E: Ax4; B X10; C X20; D X40

\section{BÀN LUÂN}

Từ kết quả nghiên cứu cho thấy: Về cơ bản cấu trúc tiểu thùy gan không thay đổi ở các lô chuột nghiên cứu, có sự thay đổi lipid trong bào tương tế bào gan chuột ở lô bình thường, lô đối chứng và lô thực nghiệm.

Bình thường lipid được chứa đựng trong bào tương tế bào gan dưới dạng hạt nhỏ, khi nhuộm Hematoxylin - Eosin thì lipid không bắt màu thuốc nhuộm biểu hiện là các hốc sáng nhỏ, khi lượng lipid càng nhiều thì càng nhiều hốc nhỏ sau đó trở thành hốc to, thậm chí chiếm toàn bộ bào tương tế bào. Ở lô đối chứng, số lượng tế bào có hạt mõ̃ trong bào tương tăng so với lô bình thường, chứng tỏ liều lượng dầu trong nghiên cứu đủ để gây tình trạng gan nhiễm mõ̃ ở chuột. Kết quả này tương tự kết quả trong 
nghiên cứu biến đổi hình thái của gan chuôt cống trắng khi nhiễm độc cấp thuốc trừ sâu Bassa đã được công bố năm 2001. Ở lô chuột thực nghiệm có sự thay đổi hình thái các tế bào gan và lượng lipid trong bào tương các tế bào gan, các tế bào nhiều lipid tập trung chủ yếu ở ngoại vi của tiểu thùy gan và lượng lipid trong bào tương tế bào giảm dân theo thời gian chuột được uống nước sắc lá sen khô, chứng tỏ nước lá sen khô có tác dụng đối với việc giảm mõ trong gan. Tuy nhiên, các nghiên cứu về lá sen trong việc giảm lượng mõ có trong gan vẫn đang được các nhà khoa học nghiên cứu, môt nghiên cứu khác trên chuột cũng cho thấy lượng cholesterol toàn phần trong huyết thanh và gan, cholesterol tứ do và phospholipids so với nhóm đối chứng chứa nhiều chất béo giảm manh. Ngoài ra, Flavonoid chất chiết xuất từ lá sen khô này còn làm giảm tổn thương gan do lượng lipid nhiều gây ra, điều này giải thích kết quả nghiên cứu của chúng tôi không thấy hình ảnh tế bào gan bị phá hủy, tổn thương.

\section{KẾT LUẬN}

Từ kết quả nghiên cứu thực nghiêm trên chuột cống trắng cho thây có sự thay đổi lượng lipid trong bào tương tế bào gan chuột khi uống nước sắc lá sen khô. Lượng lipid giảm dần theo số ngày chuột được uống nước sắc lá sen.

\section{TÀI LIÊU THAM KHẢO}

1. Bùi Thanh Thủy (2001), Nghiên cứu biến đổi hình thái gan chuột cống trắng sau nhiễm thuốc trừ sâu Bassa, Luận văn cao học, Trường Đại học Y Hà Nôi.

2. Bùi Thanh Thủy, Nguyễn Thị Hiệp Tuyết (2011), Nghiên cứu cẩu trúc mô học gan chuột nhiễm độc cấp thuốc trừ sâu nhóm carbamat sau giải độc bằng cam thảo lục đậu thang, Tạp chí Khoa học \&Công nghệ Đại học Thái Nguyên, tập 89, Số (01)/2, 2012.

3. Jiali Liu, Lina Han, Leilei Zhu, Yerong Yu (2016), Free fatty acids, not triglycerides, are associated with non-alcoholic liver injury progression in high fat diet induced obese rats. Lipids Health Dis. 2016 Feb 11;15:27

4. Joost Willebrords, Isabel Veloso Alves Pereira, Michaël Maes, Sara Crespo Yanguas, Isabelle Colle, Bert Van Den Bossche, Tereza Cristina Da Silva, Cláudia Pinto Marques Souza de Oliveira, Wellington Andraus, Venâncio Avancini Álves, Bruno Cogliati, Mathieu Vinken (2015), Strategies, models and biomarkers in experimental non-alcoholic fatty liver disease research. Prog Lipid Res. 2015 Jul;59:106-25.

\section{PHÁT HIÊN DNA MYCOBACTERIUM TUBERCULOSIS TRONG MẪU PHẾT NIÊM MẠC MIỆNG VỚI KỸ THUÂTT REAL-TIME PCR TRONG CHẨN ĐOÁN LAO PHỔI}

\section{TÓM TẮT}

Mục tiêu: Xác định giá trị chẩn đoán của xét nghiệm phát hiện DNA Mycobacterium tuberculosis trong mâ̂u phết niêm mạc miệng của bệnh nhân nghi ngờ mắc lao phổi bằng kỹ thuật real-time $P C R$ và phân tích một số yếu tố liên quan. Đối tượng và phương pháp nghiên cứu: Nghiên cứu mổ tả cắt ngang được thực hiện trên 85 bệnh nhân là người trưởng thành, nghi ngờ mắc lao phổi. Phát hiện DNA

${ }^{1}$ Đại học Y Dược Thành phố Hồ Chí Minh

${ }^{2}$ Trường Đại học Y Dược Cần Tho

${ }^{3}$ Bênh viẹn Phạm Ngọc Thach

${ }^{4}$ Trung tâm Kiểm chuẩn chất lượng xét nghiệm y học, Bộ Y tế, Đai hoc Y Dượ TP. HCM.

Chịu trách nhiệm chính: Vũ Quang Huy

Email: drvuquanghuy@gmail.com

Ngày nhận bài: 4.3.2021

Ngày phản biên khoa hoc: 23.4.2021

Ngày duyệt bài: 4.5.2021
Trần Phước Thịnh ${ }^{1,2}$, Nguyễn Hữu Lân ${ }^{3}$, Lê Văn Chương1,4, Vũ Quang Huy ${ }^{1,4}$

Mycobacterium tuberculosis trong mẫu phết niêm mạc miệng bằng kỹ thuật real-time PCR và so sánh với xét nghiệm Xpert MTB/RIF Ultra (Xpert MTB) mẫu đàm. Kết quả: Độ nhạy và độ đặc hiệu của mẫu phết niêm mạc miệng là $74,4 \%$ và $100 \%$. Mật độ vi khuẩn thấp, ăn uống trước lấy mẫu là những yếu tố có liên quan đến sự âm tính giả của mẫu phết niêm mạc miệng. Ở những bệnh nhân phải lấy đàm kích thích hoặc nộp đàm trế thì mẫu phết niêm mạc miệng cũng phát hiện DNA vi khuẩn ở 10/14 và 9/12 trường hợp theo thứ tự tương ứng. Kết luân: Nghiên cứu đã cho thấy tính khả thi của mẫu phết niêm mạc miệng và tiềm năng bổ sung cho mẫu đàm nhằm cải thiến về thời gian chẩn đoán và giảm tỷ lệ bệnh nhân phải chịu một số thủ thuật xâm lấn trong chẩn đoán lao phổi.

Tư khóa: Lao phổi, phết niêm mạc miệng, realtime PCR, Xpert MTB/RIF, sinh học phân tử.

\section{SUMMARY \\ DETECTION OF DNA MYCOBACTERIUM TUBERCULOSIS IN ORAL SWAB BY THE}

